\title{
CITRA DIRI INDIVIDU DAN NEGOSIASI MUKA WARGA DENGAN BUDAYA KOLEKTIVISME DI NEGARA BERBUDAYA INDIVIDUALISME
}

\author{
Deandra Syarizka ${ }^{1}$, Kinanthi Nareswari ${ }^{2}$, Irwansyah ${ }^{3}$ \\ irwansyah09@ui.ac.id \\ ${ }^{3}$ Program Pascasarjana Ilmu Komunikasi FISIP Universitas Indonesia
}

\section{Article Info}

Keyword:

Face Negotiation Theory; selfconstrual, collectivism culture; individualism culture; intercultural conflict

\begin{abstract}
Most of the Indonesian citizens implement a collectivism culture considering that Indonesia is one of the countries that implement a collectivism culture according to Hofstede's Cultural Dimensions Theory. Indonesian citizens who migrate and live-in countries that implement individualism culture will feel the differences in their culture, which has the potential to produce intercultural communication conflicts. The Face Negotiation Theory that was initiated by Ting-Toomey explains that there are various approaches to resolving intercultural conflicts that exist. This research analyses the concept of self-construal and intercultural communication conflict management approaches used by two Indonesian citizens who are migrating in the United States and Australia through interviews and literature studies. The results of the study found the fact that the difference in self-construal concepts by each informant could produce the different approaches in managing conflict in communication between cultures, even though both informants were from countries with collectivism cultures.
\end{abstract}

Copyright (C) 2021 Interaksi: Jurnal Ilmu Komunikasi. All rights reserved.

\section{PENDAHULUAN}

Indonesia merupakan salah satu negara yang diteliti memiliki dan menerapkan budaya kolektivisme (Hofstede, 1983). Sebagai negara yang diteliti memiliki budaya kolektivisme, sebagian besar Warga Negara Indonesia (WNI) juga diasumsikan memahami dan menerapkan budaya kolektivisme dalam hal berinteraksi, bersosialiasi, dan berkomunikasi. Sebagai bentuk dari budaya kolektivisme, segala kebiasaan (habit), sikap, dan perilaku merupakan budaya yang mengutamakan "saling ketergantungan" sehingga setiap anggota yang menjadi bagian dari kebudayaan tersebut akan membutuhkan orang lain dalam menyelesaikan segala sesuatu dalam kehidupannya seperti masalah atau konflik. Sedangkan pada budaya individualism memiliki hal yang berbeda dengan budaya kolektivisme. Anggota yang menjadi bagian dari kebudayaan individualisme mampu mengerjakan segalanya seorang diri atau menerapkan "kemandirian" masing -masing individu (Ting-Toomey, 2004).

Dalam hal mengimplementasikan komunikasi antar budaya, disadari atau tidak, baik penyampai pesan atau komunikator (sender) maupun komunikan atau penerima pesan (receiver) tetap membawa budaya asalnya masing-masing. Hal tersebut tercermin salah satunya melalui konsep citra diri (self-construal) yang dianut pada diri masing-masing (Cross, 1997). Selanjutnya, budaya asal dan konsep citra diri tersebut akan menentukan pendekatan ataupun strategi yang akan digunakan ketika menghadapi masalah atau konflik yang terjadi komunikasi antar budaya (Gudykunst, Matsumoto, Ting-Toomey, Nishida, Kim, \& Heyman, 1996), apakah menggunakan gaya dominan (dominance), menghindar (avoidance), atau integrasi (integration) (Kim, Hunter, Miyahara, Horvath, Bresnahan, \& Yoon, 1996).

Penelitian ini menganalisis konsep citra diri Warga Negara Indonesia (WNI) yang berasal dari budaya kolektivisme, dalam menghadapi konflik komunikasi antar budaya dengan individu di negara tempat mereka merantau, dalam hal ini Amerika Serikat dan Australia yang dikenal memiliki budaya individualism (Gudykunst, Matsumoto, Ting-Toomey, Nishida, Kim, 
\& Heyman, 1996).

Kedua informan dalam studi ini adalah ITD dan AR. Informan ITD merupakan WNI yang telah merantau ke Amerika Serikat selama hampir enam tahun untuk mendampingi suaminya yang tengah menimba studi doktoral (S3). Selain menjadi Ibu Rumah Tangga, informan juga aktif bekerja di bidang jasa. Konflik komunikasi yang diutarakan dalam penelitian ini merupakan konflik komunikasi yang terjadi di tempatnya bekerja.

Sementara, informan AR merupakan WNI yang tengah menempuh studi magister (S2) di Australia, dan telah merantau di negeri tersebut selama setahun lebih. Konflik komunikasi yang dijelaskan dalam penelitian ini merupakan komunikasi antar budaya mencakup rasisme yang terjadi di tempat umum, dan biasanya dilakukan oleh orang yang tidak dia kenal secara pribadi.

Penelitian ini mengeksplorasi budaya kolektivisme dan konsep diri yang dimiliki tiap-tiap informan dalam mempengaruhi pendekatan yang mereka gunakan dalam menyelesaikan konflik komunikasi antar budaya dengan warga setempat yang memiliki budaya individualisme.

\section{KAJIAN PUSTAKA}

Metodologi

Penelitian ini menggunakan metode wawancara (Kvale, 1996) dan studi literatur (Nakano \& Muniz Jr, 2018). Wawancara dilakukan melalui tiga kali pengiriman email dan dua kali tatap muka, dengan menyampaikan 20 pertanyaan yang terbagi dalam tiga skenario, yaitu fase perkenalan, fase konflik, dan fase resolusi konflik (daftar pertanyaan terlampir) (Ting-Toomey, 2004). Informan diminta untuk menjawab pertanyaan tersebut berdasarkan pengalaman dan konteks mereka berkomunikasi dengan warga negara di tempat informan tinggal sementara termasuk saat berinteraksi dengan hal-hal keseharian di lingkungan sekitarnya seperti pasar, taman, atau ruang public terbuka lainnya.

Selain itu, informan juga diminta memberikan skala ukuran mengenai faktor-faktor yang mempengaruhi pendekatan manajemen konflik yang digunakan informan, seperti hal-hal yang dipikirkan informan tentang perasaan lawan bicara atau hal-hal yang informan pikirkan tentang dampak perbuatan informan. Seluruh pertanyaan merupakan turunan dari indikator konsep citra diri (self-construal) dan facework antar-budaya (Ting-Toomey, 2004). Skala ini digunakan untuk mempermudah narasi yang diungkapkan dalam mengeksplorasi pengalaman-pengalaman yang dialami, dirasakan, dan direspon oleh informan. Penelitian ini tidak menganalisis numerik atau total jumlah angka yang diungkapkan oleh informan.

Selain melakukan wawancara, penelitian juga menggunakan metode studi literatur (Nakano \& Muniz Jr, 2018). Hal tersebut dilakukan dengan mencari referensi yang relevan dengan topik penelitian ini, seperti buku, jurnal, dan penelitian lainnya. Studi literatur ini merupakan tipe tinjauan konteks, atau memfokuskan pada topik tertentu dan diulas dengan cakupan yang lebih luas. Setidaknya ada dua penelitian terdahulu yang relevan dengan studi yang dilakukan. Penelitian sebelumnya membahas tentang teori negosiasi muka maupun konsep citra diri (self-construal) secara lebih spesifik. Salah satunya berjudul self-construal, Facework, and Conflict Styles Among Cultures in Online Learning Environment yang dilakukan oleh Sharon L. Wash, Ethel Gregory, Yvonne Lake dan Charlotte N. Gunawardena (2003). Hasil penelitiannya menemukan fakta bahwa setiap responden dari budaya yang berbeda (kolektivisme dan individualisme) umumnya sama-sama menunjukkan kebutuhan untuk menunjukkan citra yang positif dalam forum belanja online.

Penelitian lainnya yang menggunakan Teori Negosiasi Muka Ting-Toomey dilakukan oleh Eko Purwito Hidayat (2013) berjudul Manajemen Konflik dan Negosiasi Wajah dalam Komunikasi Antar Budaya Pasca Konflik Etnik Pamona dan Bugis di Poso. Hasil penelitian yang dilakukan pada 2013 itu menyimpulkan bahwa gaya penyelesaian konflik antara dua komunitas cenderung menggunakan compromising style, sementara pasca konflik menggunakan gaya menghindar (avoiding style).

Dapat dilihat bahwa kedua riset tersebut menggunakan konsep dan objek penelitian yang 
berbeda, dan belum ditemukan riset yang secara spesifik menganalisis konsep citra diri (self-construal) dan pendekatan manajemen konflik antar budaya yang dilakukan oleh WNI yang merantau ke negara individualisme, dalam hal ini Amerika Serikat dan Australia.

Konsep citra diri (self-construal) yang merupakan bagian dari Teori Negosiasi Muka atau Face Negotiation Theory (Ting-Toomey, 2004) digunakan sebagai pisau analisis. Konsep ini dipandang sebagai konsep yang menggunakan pendekatan objektif dengan proses analisis dilandaskan pada ukuran dan skala mengenai indikator konsep yang diteliti, dalam hal ini citra diri dengan pendekatan kualitatif. Analis yang digunakan dalam pemecahan permasalahan termasuk analisis tematik. Kemudian triangulasi metode digunakan dalam mengkonfirmasi hasil penelitian yang dilakukan.

\section{Kajian Konseptual}

Penelitian ini menggunakan tiga konsep. Pertama, Teori Negosiasi Muka (Face-Negotiation Theory). Teori Negosiasi Muka (Face-Negotiation Theory) merupakan sebuah konsep yang dicetuskan oleh Stella Ting-Toomey pertama kali pada tahun 1988. Teori Negosiasi Muka merupakan sebuah dasar yang digunakan manusia dalam menyelesaikan konflik antar budaya. Muka (face) ini merupakan bentuk gambar diri seseorang di hadapan orang lain. Muka merupakan gambaran yang seseorang inginkan atau jati dirinya sendiri yang ditampilkan di hadapan orang lain di dalam situasi sosial tertentu. Teori negosiasi muka ini merupakan salah satu teori yang secara tegas mengakui bahwa setiap orang yang memiliki perbedaan budaya memiliki juga perbedaan dalam pemikiran mengenai muka orang lain. Pemikiran mengenai muka orang lain ini yang menyebabkan mereka menghadapi konflik dengan cara berbeda karena muka menunjukkan konsep diri seseorang (Ting -Toomey, 2004).

Menurut Ting-Toomey (2004), muka merupakan gambaran yang sangat penting dan dibutuhkan dalam aspek kehidupan manusia. Muka juga merupakan sebuah citra diri yang diyakini melingkupi seluruh aspek kehidupan sosial (Ting-Toomey, 2004). Menurut Erving Goffman (1971), muka dijelaskan sebagai citra diri seseorang yang ditunjukkan saat berkomunikasi dengan orang lain.

Pada tahun 2004, Ting-Toomey mengembangkan pemikiran milik Goffman dengan meleburkan beberapa pemikiran dari penelitian mengenai kesantunan dengan mengatakan kebutuhan akan muka merupakan kebutuhan yang universal. Menurut Ting-Toomey (2004), muka adalah citra diri seseorang yang dibutuhkan untuk mendapatkan pengakuan serta penghargaan diri sendiri atau orang lain dalam sebuah hubungan. Ting-Toomey meyakini bahwa yang dilibatkan dalam penampilan adalah muka bagian depan (front stage) yang beradab terhadap individu lainnya. Oleh karena itu dapat dikatakan bahwa muka merupakan identitas dari dua individu yang secara bersamaan di dalam sebuah konteks komunikasi (TingToomey, 2004).

Konsep kedua dalam penelitian ini adalah budaya individualisme dan kolektivisme. Budaya merupakan hal yang dapat berubah-ubah dan seperti yang sudah dijelaskan pada bagian sebelumnya, memiliki dimensidimensi. Salah satu dimensi budaya yang diambil oleh Ting-Toomey (2004) adalah individualisme dan kolektivisme. Budaya individualisme merupakan budaya kemandirian dan budaya kolektivisme merupakan budaya saling ketergantungan. Dimensi budaya ini dianggap memiliki peran penting dalam bagaimana cara facework (Ting-Toomey \& Kurogi, 1998) dan konflik diselesaikan. Individualisme dan kolektivisme berlaku tidak hanya pada budaya nasional, melainkan juga pada sub-budaya tertentu (Ting-Toomey, 2004). Perbedaan dari individualisme dan kolektivisme dapat dirangkum sebagai berikut:

Pertama adalah individualisme (Sato \& Cameron, 1999). Karakterisitik individualisme (Hofstede, 1983) adalah (1) lebih mementingkan individu daripada kelompok dalam segala hal; (2) identitasnya "aku"; (3) melakukan komunikasi secara langsung (to the point) atau budaya komunikasi konteks rendah; (4) contoh negara yang mempraktekkan adalah Amerika Serikat, Australia, Inggris, Kanada, dan Belanda (Oetzel \& Ting-Toomey, 2003).

Kedua adalah kolektivisme (Hofstede, 1983). Kolektivisme memiliki karakteristik: (1) lebih 
mementingkan kelompok daripada individu dalam segala hal; (2) identitasnya "kita"; (3) melakukan komunikasi secara tidak langsung atau lebih banyak melakukan basa-basi atau budaya komunikasi konteks tinggi; (4) Contoh negara: Indonesia, Vietnam, Kolombia, Venezuela, dan Meksiko (Oetzel \& TingToomey, 2003).

Ketiga, kekhawatiran mengenai citra diri (face concern). Ting-Toomey (2004) menyatakan setiap citra memiliki maknanya sendiri bagi setiap orang, tergantung budaya asalnya. Kekhawatiran mengenai citra diri (face concern) pada dasarnya mempertanyakan citra diri siapa yang ingin diselamatkan ketika terjadi suatu konflik komunikasi antar budaya (Griffin, Ledbetter, Sparks, 2019). Contohnya pada budaya kolektivisme, maka face concern berbentuk muka orang lain (other face). Kemudian facework strategy: Face-giving (inklusif tidak mempermalukan orang lain). Sedangkan dalam budaya individualisme yang terjadi face concern yaitu muka diri sendiri (self-face) dengan facework strategy berbentuk face-restoration (mempertahan-kan kebebasan individu). Sedangkan untuk budaya integrasi, yang terjadi adalah face concern berupa muka diri sendiri dan orang lain (mutual face concern) (Ting-Toomey \& Kurogi, 1998).

Keempat adalah citra diri (self-construal). Banyak penelitian telah menginvestigasi hubungan konsep citra diri atau self-construal dengan negosiasi muka (Cross, 1997). Pada prinsipnya, citra diri didefinisikan sebagai konsepsi seseorang mengenai citra dirinya, yang terdiri dari interdependent dan independent self-construal (Markus \& Kitayama, 1991).

Ting-Toomey (2004) menjelaskan bahwa istilah interdependen dan independen mengacu kepada derajat di mana seseorang melihat dirinya sebagai individu yang otonom, ataupun terkoneksi dengan orang lain. Citra diri independen mengedepankan nilai-nilai ke-aku -an, sedangkan citra diri interdependen mengedepankan identitas ke-kita-an dan hubungannya dengan orang lain (Griffin, Ledbetter, \& Sparks, 2019).

Citra diri merupakan bagian dari dimensi budaya individualisme atau kolektivisme pada level individu (Gudykunst, 1995; Gudykunst \& Kim, 1997).
Gudykunst meyakini bahwa citra diri independen berhubungan dengan orang-orang dari budaya individualisme, sedangkan citra diri interdependen diasosiasikan dengan orang dari budaya kolektivisme (Matheson \& Zanna, 1988).

Dengan citra diri interdependen, perilaku seseorang ditentukan oleh pikiran, perasaan, dan perbuatan orang lain dalam suatu hubungan. Perilaku ini merupakan representasi dari budaya kolektivisme yang dideskripsikan oleh Hofstede (1983). Negara seperti Meksiko, Taiwain, India, Chile, Hong Kong, dan sebagian besar negara di Asia, termasuk Indonesia memiliki budaya kolektivisme (Markus \& Kitayama, 1991).

Sebaliknya, citra diri independen merupakan karakteristik konsep diri yang sifatnya unik. Dengan citra diri independen, perilaku diatur dan dibuat berdasarkan pemikiran, perasaan, dan tindakan diri sendiri ketimbang memikirkan pikiran, perasaan, dan tindakan orang lain (Markus \& Kitayama, 1991). Citra diri ini mirip dengan apa yang dimaksud oleh Hofstede (1983) sebagai budaya individualisme, yang menyoroti kepercayaan diri, identitas diri, citra diri dengan tujuan pribadi ketimbang kelompok, dan dengan norma interaksi yang kompetitif (Chen \& Starosta, 1998). Negara seperti Amerika Serikat, Australia, Inggris, Denmark, dan Kanada merupakan contoh negara yang memiliki budaya individualisme (Hofstede, 1983).

Kelima adalah manajemen konflik (conflict styles). Dalam menyelesaikan konflik yang ada pada negosiasi muka, berikut merupakan tahapan dalam menyelesaikan konflik tersebut yaitu dimulai dari budaya yang dimiliki tiap individu mempengaruhi muka mana yang mau ditunjukkan saat terjadinya konflik dan dalam penyelesaian konflik tersebut, tiap individu akan memilih manajemen konflik yang digunakan dalam menyelesaikan konflik tersebut (TingToomey, 1988).

Menurut Ting-Toomey (2004), terdapat lima gaya manajemen konflik dalam menyelesaikan konflik yang terjadi: Pertama, avoiding style atau withdrawing merupakan manajemen konflik dimana biasanya individu tidak ingin berada pada situasi konflik dan berusaha menghindari konflik yang ada. Kedua, oblig- 
ing style atau accommodating merupakan manajemen konflik dimana biasanya individu mencoba untuk memberikan opsi-opsi dalam penyelesaian konflik tetapi tidak aktif dalam penyelesaian konflik tersebut. Ketiga, compromising style atau bargaining merupakan manajemen konflik dimana biasanya individu akan berkompromi dengan mencari jalan damai atau saling mengurangi tuntutan dari konflik yang ada. Keempat, dominating style atau competing merupakan manajemen konflik dimana biasanya individu mementingkan kepentingan dan keuntungan pribadi saat menyelesaikan konflik yang ada. Kelima, integrating style atau problem solving merupakan manajemen konflik dimana biasanya individu-individu yang memiliki konflik saling bertukar pikiran agar konflik yang ada dapat diselesaikan dengan cara winwin solution (Ting-Toomey, 2004).

Kelima gaya manajemen konflik tersebut kemudian mengalami pembaruan dengan adanya konsep self-construal atau citra diri. Dengan adanya konsep citra diri, Ting-Toomey (2004) menyatakan ada tiga pendekatan manajemen konflik (conflict styles) yang biasa digunakan seseorang guna memenuhi kebutuhan terhadap face concern, antara lain: Pertama, conflict styles dengan dominan (dominance) melalui (1) mempertahankan pendapat (defend); (2) mengekspresikan emosi; (3) agresi. Bentuk face concern adalah citra diri sendiri (self-face). Kedua, conflict styles dengan menghindar (avoidance) melalui (1) mengalah (give in); (2) berpura-pura tidak ada masalah (pretend); (3) mencari bantuan pihak ketiga. Bentuk face concern adalah citra diri orang lain (other face). Ketiga, conflict styles dalam bentuk integrasi (integration) melalui (1) meminta maaf; (2) mengajak bicara secara pribadi (private talk); (3) tetap tenang; (4) memecahkan masalah bersama-sama; dan (5) menghargai lawan bicara. Bentuk face concern adalah citra diri sendiri dan orang lain (mutual face).

Konsep citra diri (self-construal) turut mempengaruhi preferensi seseorang dalam menentukan pendekatan (Cross, 1997) seperti apa yang akan digunakan dalam manajemen konflik komunikasi antar budaya (Griffin, Ledbetter, \& Sparks, 2019). Dengan demikian, skema penyelesaian konfliknya menjadi: Type of Culture $\square$ Self-Construal $\square$ Face Concern $\square$
Conflict Style.

Keenam adalah facework Antar Budaya. Tujuan utama Ting-Toomey (2004) mengembangkan Teori Negosiasi Muka adalah untuk mengidentifikasi bagaimana seseorang dengan budaya yang berbeda dapat saling bernegosiasi atau menyelesaikan masalah satu sama lain. Ting-Toomey merekomendasikan syarat -syarat untuk mendapatkan facework antar-budaya yang berkompeten. Tiga syarat tersebut adalah knowledge, mindfulness, dan interaction skill.

Knowledge merupakan dimensi paling penting dalam facework antar-budaya. Pengetahuan yang luas tentang kebudayaan dari orang yang sedang bernegosiasi muka dengan kita mampu membantu kita untuk bisa memberikan respon yang sesuai saat konflik terjadi. Mindfulness berarti secara khusus menyadari asumsi, sudut pandang, dan etnosentris sendiri dalam memasuki situasi asing apapun yang tidak kita ketahui. Mindfulness juga dapat berarti memperhatikan perspektif dan lensa interpretif dimata orang lain dalam melihat suatu komunikasi antar-budaya. Interaction skill merupakan kemampuan seseorang dalam berkomunikasi secara tepat, efektif, dan adaptif dalam situasi tertentu (Ting-Toomey, 2004). Dengan syaratsyarat yang diberikan oleh Ting-Toomey menjadikan facework antar-budaya akan terjadi secara kompeten

\section{TEMUAN DAN DISKUSI}

Hasil penelitian ini membagi skenario daftar pertanyaan ke dalam tiga fase, yaitu fase perkenalan, fase konflik dan fase resolusi konflik. Fase perkenalan berisikan pertanyaan mengenai cara informan ingin mengenalkan dan merepresentasikan konsep dirinya kepada orang lain dan proses informan mengenali perbedaan budaya antara negara asal dengan negara tempat mereka merantau. Fase konflik berisi pertanyaan mengenai pengalaman responden dalam menghadapi masalah komunikasi antar budaya. Pertanyaan yang dimaksud mencakup frekuensi mengalami konflik, deskripsi penyebab konflik, serta reaksi informan ketika konflik itu berlangsung, cara informan memikirkan perasaan lawan bicaranya atau tidak, dan cara informan memikirkan dampak dari tindakannya 
terhadap orang lain. Fase resolusi konflik berisi pertanyaan mengenai pendekatan seperti apa yang responden gunakan ketika menyelesaikan konflik komunikasi antar budaya. Pertanyaannya terdiri dari cara dan pendekatan komunikasi yang digunakan, serta sejumlah pertanyaan lainnya yang meminta informan memberikan skala untuk mengukur kecenderungan gaya manajemen konflik (conflict styles) yang informan gunakan, apakah menunjukkan gaya dominan (dominance), menghindar (avoidance) atau integrasi (integration).

Ting-Toomey (2004) menjelaskan, ketiga gaya manajemen konflik tersebut menggambarkan face concern yang dimiliki tiap informan. Seseorang yang mengutamakan atau memiliki face concern "muka" atau citra dirinya sendiri atau individualis, biasanya akan menggunakan pendekatan dominan, sedangkan seseorang yang mengutamakan "muka" atau citra diri orang lain atau kolektivis, cenderung menggunakan pendekatan menghindar. Sementara, seseorang yang memiliki face concern atau sama-sama mengutamakan citra dirinya dan orang lain (mutual face), biasanya akan menggunakan pendekatan integrasi.

Dari hasil wawancara dengan kedua informan, penelitian ini menemukan kecenderungan yang berbeda. Dalam kasus informan ITD khususnya fase perkenalan, memperlihatkan informan masih menganut budaya kolektivisme Indonesia, dan informan memiliki keinginan yang cukup tinggi untuk memperkenalkan budayanya, baik secara sadar atau tidak sadar.

Meskipun berasal dari Indonesia yang kental dengan budaya kolektivisme, namun responden tersebut terlihat memiliki citra diri (self-construal) yang independen. Hal ini tercermin dari perilakunya ketika menghadapi fase konflik komunikasi antar budaya dengan kolega kerjanya, informan ITD sangat menghargai otonomi dan mengutamakan hak dirinya. Dengan kata lain, kekhawatiran mengenai citra (face concern) yang dimiliki informan adalah mengenai citra dirinya sendiri (self-face).

Menariknya, dalam fase resolusi konflik, informan cenderung menggunakan pendekatan manajemen konflik (conflict styles) yang merupakan perpaduan antara pendekatan dominan, menghindar, dan integrasi sekaligus. Pendekatan dominan dilakukan dengan mempertahankan pendapat dan mengekspresikan perasaannya, sedangkan pendekatan menghindar dilakukan dengan meminta bantuan pihak ketiga untuk memediasi. Sementara, pendekatan integrasi yang dilakukan yaitu dengan mengajak koleganya berbicara secara personal sambil tetap menghargai pendapatnya.

Penelitian ini juga menganalisis kombinasi dari ketiga pendekatan manajemen konflik ini merupakan perpaduan dari budaya kolektivisme Indonesia yang merupakan daerah asal informan (Saputra, 2019), dengan konsep citra diri independen yang dimiliki informan. Seperti telah dijelaskan sebelumnya, konsep diri independen umumnya berkaitan dengan individu yang berasal dari negara dengan budaya individualisme.

Selanjutnya, penelitian ini menemukan sejumlah kesamaan dan juga perbedaan dengan hasil wawancara dengan informan AR. Dalam kasus yang terjadi pada informan $\mathrm{AR}$, khususnya pada fase perkenalan, penelitian ini menemukan bahwa informan masih menganut budaya kolektivisme Indonesia, seperti dengan ucapan 'kita'. Informan AR juga memiliki keinginan yang kuat untuk memperkenalkan budayanya secara sadar kepada teman-teman dan lingkungan tempat tinggalnya. Misalnya dengan memperkenalkan cara-cara dalam kehidupan sehari-hari di Indonesia.

Perbedaannya terletak pada konsep citra diri (selfconstrual) dan gaya manajemen konflik yang dimiliki kedua informan. Hasil wawancara menunjukkan bahwa konsep citra diri yang dimiliki informan AR yang memiliki konsep citra diri interdependen. Hal ini tercermin dari perilakunya ketika menghadapi fase konflik komunikasi rasisme yang seringnya dilakukan oleh orang yang tidak dikenalnya. Informan AR lebih memilih menghindar dan berpura-pura tidak ada masalah ketimbang menghadapinya. Dengan kata lain, kekhawatiran mengenai citra (face concern) yang dimiliki informan adalah mengenai citra orang lain (other-face).

Adapun dalam konflik komunikasi antar budaya yang dihadapi dengan orang asing di Australia, informan AR cenderung menggunakan pendekatan manajemen konflik kombinasi antara menghindar (avoidance) dan integrasi. Pendekatan menghindar 
dilakukan dengan cara mengalah, berpura-pura tidak terjadi masalah, hingga meminta bantuan pihak ketiga. Sementara, pendekatan integrasi diterapkan melalui kesediaan responden untuk meminta maaf, mengajak bicara secara pribadi, hingga menunjukkan penghargaan terhadap lawan bicara. Informan sama sekali tidak menunjukkan gaya pendekatan yang dominan, baik dengan mempertahankan pendapat, mengekspresikan perasaan, maupun melakukan tindakan agresif. Berikut adalah rangkuman jawaban dari kedua informan:

\section{Tabel 1. Hasil Informan ITD}

\begin{tabular}{|c|c|}
\hline Pertanyaan & $\begin{array}{l}\text { Jawaban dari Informan } \\
\text { ITD dalam Skala 1-10 }\end{array}$ \\
\hline $\begin{array}{l}\text { Sejauh mana Anda } \\
\text { ingin mengenalkan } \\
\text { budaya asal? }\end{array}$ & $\begin{array}{l}7 \text { (ingin mengenalkan): } \\
\text { Indonesia negara kaya bu- } \\
\text { daya, paling tidak mereka } \\
\text { tahu adanya Indonesia }\end{array}$ \\
\hline $\begin{array}{l}\text { Sejauh mana Anda } \\
\text { mengutamakan } \\
\text { perasaan Anda ketim- } \\
\text { bang orang lain? }\end{array}$ & $\begin{array}{l}1 \text { (sangat mengutamakan } \\
\text { perasaan diri sendiri): } \\
\text { Perasaan tentang diri } \\
\text { sendiri adalah yang utama }\end{array}$ \\
\hline $\begin{array}{l}\text { Sejauh mana Anda } \\
\text { memikirkan dampak } \\
\text { tindakan Anda ter- } \\
\text { hadap orang lain? }\end{array}$ & $\begin{array}{l}\text { 1 (tidak memikirkan): } \\
\text { Selalu fokus dengan tinda- } \\
\text { kan bukan akibat }\end{array}$ \\
\hline $\begin{array}{l}\text { Sejauh mana Anda } \\
\text { mempertahankan } \\
\text { pendapat/argumentasi } \\
\text { Anda? }\end{array}$ & $\begin{array}{l}10 \text { (sangat mempertahan- } \\
\text { kan): Selama kita yakin } \\
\text { maka kita perlu bertahan }\end{array}$ \\
\hline $\begin{array}{l}\text { Sejauh mana Anda } \\
\text { mengekspresikan } \\
\text { perasaan Anda? }\end{array}$ & $\begin{array}{l}10 \text { (sangat mengekspresi- } \\
\text { kan): perasaan harus } \\
\text { dinyatakan secara eksplisit } \\
\text { karena dengan demikian }\end{array}$ \\
\hline $\begin{array}{l}\text { Sejauh mana Anda } \\
\text { bersedia mengalah? }\end{array}$ & $\begin{array}{l}2 \text { (kurang bersedia): tidak } \\
\text { ada alasan untuk mengalah } \\
\text { ketika kita menang }\end{array}$ \\
\hline $\begin{array}{l}\text { Sejauh mana Anda } \\
\text { berpura-pura tidak } \\
\text { terjadi komunikasi? }\end{array}$ & $\begin{array}{l}\text { 1 (tidak berpura-pura): } \\
\text { Sudah pasti kelihatan jika } \\
\text { tidak ada komunikasi yang }\end{array}$ \\
\hline $\begin{array}{l}\text { Sesering apa Anda } \\
\text { meminta bantuan } \\
\text { pihak ketiga? }\end{array}$ & $\begin{array}{l}8 \text { (cukup sering meminta } \\
\text { bantuan): Ketika kita ek- } \\
\text { spresif maka mudah } \\
\text { meminta bantuan kepada } \\
\text { orang lain }\end{array}$ \\
\hline $\begin{array}{l}\text { Sejauh mana Anda } \\
\text { bersedia meminta } \\
\text { maaf? }\end{array}$ & $\begin{array}{l}10 \text { (sangat bersedia) bila } \\
\text { kesalahan informan, } 1 \\
\text { (tidak bersedia) bila bukan } \\
\text { kesalahan responden: } \\
\text { Minta maaf dan tidak } \\
\text { minta maaf harus jelas } \\
\text { sebabnya }\end{array}$ \\
\hline $\begin{array}{l}\text { Sesering apa Anda } \\
\text { akan mengajak bicara } \\
\text { lawan bicara secara } \\
\text { pribadi mengenai } \\
\text { konflik yang terjadi? }\end{array}$ & $\begin{array}{l}5 \text { (netral): kadang perlu } \\
\text { kadang juga tidak perlu }\end{array}$ \\
\hline
\end{tabular}

Sejauh mana Anda bersedia mengakomodir kepentingan kedua belah pihak?

Sejauh mana Anda akan menunjukkan penghargaan terhadap lawan bicara?
10 (sangat bersedia): Ketika kita bisa mengakomodasi siapapun maka sebaiknya dilakukan 10 (sangat menunjukkan): Perasaan yang ekspresif sangat penting ketika merespon atau menghargai orang lain

Tabel 2. Hasil Informan AR

\begin{tabular}{|c|c|}
\hline Pertanyaan & $\begin{array}{l}\text { Jawaban dari informan } \\
\text { AR dalam Skala 1-10 }\end{array}$ \\
\hline $\begin{array}{l}\text { Sejauh mana Anda } \\
\text { ingin mengenalkan } \\
\text { budaya asal? }\end{array}$ & $\begin{array}{l}8 \text { (sangat ingin mengenal- } \\
\text { kan): Budaya Indonesia } \\
\text { menarik untuk diperkenal- } \\
\text { kan }\end{array}$ \\
\hline $\begin{array}{l}\text { Sejauh mana Anda } \\
\text { mengutamakan } \\
\text { perasaan Anda } \\
\text { ketimbang orang } \\
\text { lain? }\end{array}$ & $\begin{array}{l}10 \text { (sangat mengutamakan } \\
\text { perasaan orang lain): Sen- } \\
\text { sitif menjadi penting ten- } \\
\text { tang perasaan orang lain }\end{array}$ \\
\hline $\begin{array}{l}\text { Sejauh mana Anda } \\
\text { memikirkan dampak } \\
\text { tindakan Anda ter- } \\
\text { hadap orang lain? }\end{array}$ & $\begin{array}{l}6 \text { (cukup memikirkan): } \\
\text { Setiap tindakan memiliki } \\
\text { dampak bagi orang lain }\end{array}$ \\
\hline $\begin{array}{l}\text { Sejauh mana Anda } \\
\text { mempertahankan } \\
\text { pendapat/ } \\
\text { argumentasi Anda? }\end{array}$ & $\begin{array}{l}3 \text { (kurang begitu memper- } \\
\text { tahankan): pendapat } \\
\text { pribadi tidak penting }\end{array}$ \\
\hline $\begin{array}{l}\text { Sejauh mana Anda } \\
\text { mengekspresikan } \\
\text { perasaan Anda? }\end{array}$ & $\begin{array}{l}1 \text { (tidak mengekspresikan): } \\
\text { Penting untuk tidak mem- } \\
\text { perlihatkan perasaan di } \\
\text { depan orang lain }\end{array}$ \\
\hline $\begin{array}{l}\text { Sejauh mana Anda } \\
\text { bersedia mengalah? }\end{array}$ & $\begin{array}{l}8 \text { (sangat bersedia): Jika } \\
\text { untuk kepentingan bersa- } \\
\text { ma, maka kadang kita per- } \\
\text { lu mengalah }\end{array}$ \\
\hline $\begin{array}{l}\text { Sejauh mana Anda } \\
\text { berpura-pura tidak } \\
\text { terjadi komunikasi? }\end{array}$ & $\begin{array}{l}4 \text { (cukup berpura-pura): } \\
\text { Kadang kita perlu tidak } \\
\text { memperhatikan ada atau } \\
\text { tidaknya komunikasi }\end{array}$ \\
\hline $\begin{array}{l}\text { Sesering apa Anda } \\
\text { meminta bantuan } \\
\text { pihak ketiga? }\end{array}$ & $\begin{array}{l}9 \text { (sangat sering): Tinggal } \\
\text { di luar sangat memerlukan } \\
\text { bantuan orang lain }\end{array}$ \\
\hline $\begin{array}{l}\text { Sejauh mana Anda } \\
\text { bersedia meminta } \\
\text { maaf? }\end{array}$ & $\begin{array}{l}10 \text { (sangat bersedia): Kalau } \\
\text { kita salah sudah saatnya } \\
\text { menyatakan dengan tepat }\end{array}$ \\
\hline $\begin{array}{l}\text { Sesering apa Anda } \\
\text { akan mengajak } \\
\text { bicara lawan bicara } \\
\text { secara pribadi } \\
\text { mengenai konflik } \\
\text { yang terjadi? }\end{array}$ & $\begin{array}{l}10 \text { (sangat sering): Me- } \\
\text { nyelesaikan konflik perlu } \\
\text { dilakukan secepatnya un- } \\
\text { tuk menenangkan pikiran }\end{array}$ \\
\hline
\end{tabular}




\begin{tabular}{|l|l|}
\hline $\begin{array}{l}\text { Sejauh mana Anda } \\
\text { bersedia mengako- } \\
\text { modir kepentingan } \\
\text { kedua belah pihak? }\end{array}$ & $\begin{array}{l}\text { 1 (tidak bersedia): } \\
\text { Tipikal untuk mengako- } \\
\text { modir tidak pernah ter- } \\
\text { pikirkan sebelumya }\end{array}$ \\
\hline $\begin{array}{l}\text { Sejauh mana Anda } \\
\text { akan menunjukkan } \\
\text { penghargaan ter- } \\
\text { hadap lawan } \\
\text { bicara? }\end{array}$ & $\begin{array}{l}10 \text { (sangat menunjuk- } \\
\text { kan): Orang lain perlu } \\
\text { secara eksplisit melihat } \\
\text { adanya penghargaan } \\
\text { sehingga mereka akan } \\
\text { menghargai kembali }\end{array}$ \\
\hline
\end{tabular}

Dengan mengacu pada konsep skema manajemen konflik Ting-Toomey (2004) dan hasil wawancara dalam kasus informan ITD dan AR, skema komunikasi yang terjadi pada masing-masing responden adalah: Pertama, pada informan ITD, budaya kolektivisime terjadi dengan adanya independensi dari informan. Keadaan ini menciptakan citra diri sendi (selfface) dengan melakukan strategi dominan, menghindar, dan integrasi (Kolektivisme $\square$ Independen $\square$ Citra Diri Sendiri (Self-Face) $\square$ Dominan + Menghindar + Integrasi). Kedua, pada informan AR yang memiliki budaya kolektivisme memperlihatkan adanya interdependen. Informan AR melakukan pembentukan citra orang lain (other face) dengan strategi menghindar dan integrasi (Kolektivisme $\square$ Interdependen $\square$ Citra Orang Lain (Other Face) $\square$ Menghindar + Integrasi).

Studi ini memperlihatkan bahwa kedua informan walaupun memiliki budaya kolektivisme, keduanya memiliki karakteristik yang berbeda dalam citra diri (self-construal) yaitu bersifat independen dan interdependen. Kedua karakteristik dalam citra diri (self-construal) ini menyebabkan munculnya strategi dalam berhadapan dengan orang lain atau dalam menyelesaikan konflik yang sering menimbulkan perbedaan. Studi sebelumnya (Oetzel \& Ting-Toomey, 2003) memperlihatkan bahwa budaya kolektivisme memiliki pengaruh langsung dan tidak langsung pada gaya konflik (conflict style). Misalnya independent self -construal berhubungan dengan self-face, sedangkan interdependent self-construal berkaitan dengan otherface (Sato \& Cameron, 1999). Kemudian self-face berkaitan dengan gaya konflik yang dominan sedangkan other-face berkaitan dengan menghindar dan mengintegrasi.

Kemudian tiga syarat seperti knowledge, mindfulness, dan interaction skill menjadi bagian yang membentuk self-construal dalam menyelesaikan konflik (Ting-Toomey, 2004). Contohnya dengan pengetahuan yang baik, maka strategi dalam menyelesaikan konflik bisa saja berubah pada konteks tertentu. Perhatian juga menjadi bagian yang penting dalam menyelesaikan strategi yang dipilih untuk menghadapi konflik. Demikian juga dengan interaksi, karena pada saat interaksi terjadi secara langsung strategi di lapangan saat menyelesaikan konflik dapat berubah sesuai dengan situasi yang terjadi. Oleh karena itu budaya kolektivisme tidak menjadi bahwa strategi yang dipilih akan selalu sama. Apalagi di dalam budaya kolektivisme selalu ada orang-orang dengan berbagai kepribadian, karakter, latar belakang sejarah, pendidikan, etnisitas (Ting-Toomey, et al. 2000), dan keluarga (Sato \& Cameron, 1999) dapat membentuk citra diri (self-construal) menjadi independen atau interdependen (Matheson \& Zanna, 1988).

Dengan demikian keberadaan citra diri (selfconstrual) yang independen ataupun interdependen mampu memilih dengan baik strategi yang tepat dalam menyelesaikan masalah atau konflik (Sato \& Cameron, 1999). Salah satu bagian yang penting adalah kombinasi atau gabungan dari pengetahuan, perhatian, dan atau interaksi dapat menentukan strategi dalam menyelesaikan konflik. Hal ini sebagai cara bertahan bagi warga negara yang berbeda budaya (kolektivisme atau individualisme) di negara yang memiliki budaya yang berbeda juga.

\section{KESIMPULAN}

Penelitian ini menemukan bahwa individu yang berasal dari budaya kolektivisme kemudian tinggal di suatu negara individualisme merasakan adanya perbedaan budaya. Perbedaan budaya itulah yang turut menjadikan individu tersebut memiliki keinginan tinggi untuk menerapkan dan mengenalkan budaya asalnya kepada orang setempat.

Dalam konteks manajemen konflik komunikasi antar budaya, pendekatan (conflict styles) yang digunakan seseorang tak hanya dipengaruhi oleh budaya asalnya saja, tetapi juga konsep citra diri yang 
dimilikinya. Meskipun berasal dari budaya yang sama, perbedaan konsep citra diri seseorang menjadi salah satu faktor yang membuat pendekatan manajemen konflik komunikasi antar budaya yang digunakan menjadi berbeda.

Berdasarkan analisis teori dan hasil wawancara dari kedua informan, dapat disimpulkan bahwa meskipun informan menerapkan budaya kolektivisme, tetapi dirinya memiliki citra diri yang independen. Oleh sebab itu, informan seperti ini memiliki tipe kekhawatiran mengenai citra (face-concern) dirinya sendiri (self-face).

Uniknya adalah walaupun memiliki citra diri yang independen dan memiliki face-concern citra dirinya sendiri, informan berusaha tetap memadukan budaya kolektivisme saat menyelesaikan konflik yang ada. Dengan demikian, dapat disimpulkan bahwa seseorang yang cenderung menggunakan perpaduan tiga pendekatan yaitu dominan, menghindar, dan integrasi secara bersamaan dalam menyelesaikan konflik komunikasi antar-budayanya.

Berdasarkan analisis teori dan hasil wawancara informan lainnya, ditemukan fakta bahwa karakteristik informan berbeda antara satu dengan lainnya. Walaupun masih sama-sama menerapkan budaya kolektivisme tetapi dalam menggunakan citra dirinya memiliki karakteristik interdependen. Oleh sebab itu, informan yang independen seperti ini memiliki kekhawatiran mengenai citra (face-concern) adalah citra orang lain (other-face). Dengan demikian, seseorang yang memiliki karakteristik interdependen cenderung menggunakan perpaduan pendekatan menghindar dan integrasi secara bersamaan dalam menyelesaikan konflik.

Perbedaan citra diri yang dimiliki tiap-tiap seseorang dalam budaya kolektivisme baik dengan citra diri yang independen dan interdependen dapat menghasilkan perbedaan pendekatan dalam manajemen konflik komunikasi antar budaya. Keberadaan di negara yang bersifat individualis tidak mengurangi impelementasi dari budaya kolektivisme. Yang menimbulkan perbedaan dalam strategi konflik adalah karakteristik dari citra diri. Dengan demikian, dapat dikatakan bahwa citra diri, kekhawatiran mengenai citra, dan budaya asal seseorang sangat penting dalam menentukan cara seseorang menyelesaikan konflik.

Penelitian ini memberikan kontribusi bahwa budaya kolektivisme dengan karakter citra diri baik independen dan interdependen menciptakan cara-cara atau strategi tertentu dalam menyelesaikan konflik. Oleh karena itu penelitian lebih lanjut sebaiknya mengeksplorasi kebalikan dari penelitian ini yaitu menggali orang-oang dengan budaya individualism yang memiliki karakter independen dan interdependen memiliki strategi dominan, menghindar atau integrasi. Penelitian lebih lanjut juga sebaiknya mengeksplorasi lebih detail secara kualitatif proses perubahan warga negara yang memiliki budaya kolektivisme kemudian kembali ke negaranya dalam menyelesaikan konflik yang terjadi ketika berkomunikasi dengan orang lain.

Selanjutnya penelitian lebih lanjut sebaiknya mengeksplorasi citra diri (self-construal) dengan karakter budaya lokal secara spesifik dengan tidak hanya melihat secara umum tentang kolektivisme. Dengan demikian generalisasi yang selama ini dilakukan dalam penelitian sebelumnya dapat lebih menggali kearifan lokal. Proses yang terjadi juga dapat mengeksplorasi bentuk-bentuk strategi yang menggabungkan antara dominan-menghindar, dominan-integrasi, dan menghindar-integrasi, atau gabungan dominanmenghindar-integrasi. Penelitian secara khusus juga sebaiknya mengatribusi jenis kelamin sebagai pembentuk self-contrual dalam membentuk strategi menyelesaikan konflik.

\section{DAFTAR PUSTAKA}

Chen, G. M, \& Starosta, W.J. (1998-9). A review of the concept of intercultural awareness. Human Communication, 2, 27-54.

Cross, S.E. (1997). Models of the self: Self-construals and gender. Psychological Bulletin, 122, 5-37

Goffman, Erving. (1971). The Presentation Of Self In Everyday Life. London: Cox \& Wyman Ltd, London. Reading and Fakenham Set in Intertype Times, Pelican Books.

Griffin, Emory, Ledbetter, Andrew and Sparks, Glenn 
(2019). A First Look at Communication Theo-

$r y$, 10th Edition. New York: McGraw-Hill Education.

Gudykunst, W. B. (1995). Anxiety/uncertainty management (AUM) theory: Current status. In R. L.Wiseman (Ed.), Intercultural communication theory (pp. 8-58). Thousand Oaks, CA: Sage.

Gudykunst, W. B., \& Kim, Y. Y. (1997). Communicating with strangers: An approach to intercultural communication ( $3 r d$ ed). New York: McGraw-Hill.

Gudykunst, W.B., Matsumoto, Y., Ting-Toomey, S., Nishida, T., Kim, K., \& Heyman, S. (1996). The influence of cultural individualismcollectivism, selfconstruals, and individual values on communication styles across cultures. Human Communication Research, 22, 510-543.

Hidayat, Eko P. (2013) Manajemen Konflik dan Negosiasi Wajah dalam Komunikasi Antar Budaya Pasca Konflik Etnik Pamona dan Bugis di Poso, tesis yang tidak diterbitkan, Salemba: Universitas Indonesia.

Hofstede, G. (1983). National Cultures Revisited. Behavior Science Research, 18(4), 285-305.

Kim, M.S., Hunter, J.E., Miyahara, A., Horvath, A., Bresnahan, M., \& Yoon, H. (1996). Individuals, cultural-level dimensions of individualism and collectivism: Effects on preferred conversational styles. Communication Monographs, 63, 28-49.

Kvale, Steinar (1996). Interviews: An Introduction to Qualitative Research Interviewing, Thousand Oaks, California, Amerika: Sage Publications.

Markus, H. R., \& Kitayama, S. (1999). Culture and the self: Implications for cognition, emotion, and motivation. In R. F. Baumeister (Ed.), Key readings in social psychology. The self in social psychology (p. 339-371). Psychology Press.
Matheson, K., \& Zanna, M.P. (1988). The impact of computer-mediated communication on selfawareness. Computers in Human Behavior, 4, 221-223

Nakano, D., \& Muniz Jr, J. (2018). Writing the literature review for empirical papers. Producation, 28, e20170086. https://doi.org/10.1590/01036513.20170086 .

Rahayu, S.K. (2019). Face Negotiation dalam Котиnikasi Antar Budaya Karyawan Asing dan Indonesia. Tesis yang tidak diterbitkan, Jakarta: Universitas Indonesia.

Saputra, E. (2019). Komunikasi antarbudaya etnis lokal dengan etnis pendatang : Studi pada mahasiswa/i fakultas adab dan ilmu budaya UIN Sunan Kalijaga Yogyakarta. Interaksi: Jurnal Ilmu Komunikasi, 8(1), 28-40. https:// doi.org/10.14710/interaksi.8.1.28-33

Sato, T., \& Cameron, J.E. (1999). The relationship between collective self-esteem and self-construal in Japan and Canada. Journal of Social Psychology, 139, 426-436.

Ting-Toomey, S. (1988). Intercultural conflict style: A face-negotiation theory. In Y.Y. Kim and W.B. Gudykunst (Eds.), Theories in intercultural communication (pp. 213-235). Newbury Park, CA: Sage.

Ting-Toomey, S. (2004). Understanding Intercultural Communication 2nd Edition. United Kingdom: Oxford University Press.

Ting-Toomey, S., \& Kurogi, A. (1998). Facework competence in intercultural conflict: An updated face negotiation theory. International Journal of Intercultural Relations, 22, 187-225.

Ting-Toomey, S., Yee-jung, K.K., Shapiro, R.B., Garcia, W., Wright, T.J., \& Oetzel, J.G. (2000). Ethnic/cultural identity salience and conflict styles in four US ethnic groups. International Journal of Intercultural Relations, 24, 47-81.

Walsh, Sharon, Gregory, Ethel, Lake, Yvonne \& Gunawardena, Charlotte. (2003). Self-construal, facework, and conflict styles among cultures 
in online learning environments. Educational

Technology Research and Development. 51.

113-121. 10.1007/BF02504548. 